Keio J. Med. 24: 355-365, 1975

\title{
ANTIGENIC DETERMINANTS SHARED BY RAT LYMPHOCYTES AND RAT BRAIN SUBCELLULAR FRACTIONS
}

\author{
B. D. JANKOVIC, J. HORVAT, K. MITROVIC and M. MOSTARICA \\ Immunology Research Center, Belgrade, Yugoslavia
}

\begin{abstract}
Anti-rat brain synaptic membrane, synaptic vesicle and microsome sera prepared in rabbits were tested against rat thymocytes ( $\mathrm{T}$ cells) and bone marrow (B) cells. Unabsorbed antisera produced cytotoxic effect and positive fluorescence with both $\mathrm{T}$ and $\mathrm{B}$ cells. However, antisera absorbed with $\mathrm{B}$ cells and $T$ cells did not react with $B$ and $T$ cells respectively. Absorption of antisera with $\mathbf{T}$ cells markedly reduced the anti- $\mathrm{B}$ activity, whereas absorption with B cells was less effective in removing the anti-T activity. The most important finding was that anti-synaptic vesicle serum, although properly absorbed with $T$ cells, exerted a specificity for $B$ cells in cytotoxicity and immunofluorescence assays.

The cytotoxic and immunofluorescent effects caused by absorption of antisera with $T$ and $B$ cells may indicate that there are at least three serologically different antigenic determinants on the surface of rat lymphocytes: Thy-1 antigen which is specific for $T$ cells, B antigen which is specific for $B$ cells, and $\mathrm{C}$ antigen which is a common antigen for both. These antigenic markers are shared by rat brain and rat lymphocytes. The largest amount of Thy-1 antigen seems to be present in synaptic membranes and vesicles, of $B$ antigen in vesicles, and of $\mathrm{C}$ antigen in microsomes of the rat brain.
\end{abstract}

\section{INTRODUCTION}

Mouse thymocytes ( $\mathrm{T}$ cells) and brain share the so-called Thy-l $(\theta)$ antigen. ${ }^{1}$ An analogue of the mouse Thy-l marker has been found in rat thymocytes and brain. ${ }^{2,3}$ The cell surface antigenic determinants of lymphocytes can be demonstrated by alloantisera and heteroantisera, ${ }^{4}$ rabbit anti-brain serum being considered a highly specific reagent for detection of $\mathrm{T}$ cells in mice and rats. ${ }^{5}$ So far, anti-brain sera specific for $\mathrm{T}$ cells have been produced by immunizing animals with the whole brain tissue. However, the brain is not only an organ of immense structural and functional complexity but also a tissue of extraordinary and dynamic antigenic heterogeneity. ${ }^{\circ}$ Consequently, the use of antisera raised in 
rabbits against different subcellular fractions of the brain, instead of an antiserum against the whole brain, may provide more precise answers to fundamental questions concerning the common brain-lymphocyte antigenic determinants. The present report deals, therefore, with a study of inter-relationships between brain antigens and antigens associated with cell surface of lymphocytes by means of rabbit antisera produced with synaptic membranes, synaptic vesicles and microsomes of the rat brain.

\section{MATERIALS AND METHODS}

\section{Animals :}

Wistar rats and chinchilla rabbits were used in the experiment. B rats, which served as donors of bone marrow cells (B cells), were thymectomized at birth, then 2 weeks later irradiated with $700 \mathrm{r}(200 \mathrm{kv}, 17 \mathrm{mV}, 3 \mathrm{~mm}$ Al filter, distance of $50 \mathrm{~cm}$, and $160 \mathrm{r} / \mathrm{min}$ ), and used when six weeks old.

\section{Brain, thymus and bone marrow:}

Brain, thymus and bone marrow samples were obtained from rats which was thoroughly perfused with saline in order to remove blood lymphocytes from the tissues.

\section{Brain microsomes:}

Rat brain microsomes were prepared according to the method of Tashiro and Siekevitz.?

\section{Brain synaptic membranes and vesicles:}

The method of Lapetina et al. ${ }^{8}$ was employed for the isolation of subcellular fractions from the rat brain. The synaptic vesicles were obtained as a $\mathbf{M}_{2} \mathrm{~A}$ layer in the sucrose gradient, and the membranes as a pellet after centrifugation at $50,000 \times \mathrm{g}$ for $1 \mathrm{hr}$. The homogeneity of synaptic membrane and synaptic vesicle preparations was controlled by electron microscope examinations.

\section{Anti-rat brain subcellular fraction sera:}

From 16 to $20 \mathrm{mg}$ of lyophilized synaptic membranes, synaptic vesicles or brain microsomes were homogenized in saline, emulsified in an equal volume of complete Freund's adjuvant, and injected subcutaneously into rabbits. Animals were reinjected at monthly intervals, and serum samples were heated at $56^{\circ} \mathrm{C}$ for $20 \mathrm{~min}$ before absorption.

\section{Absorption of rabbit antisera:}

The first absorption was performed with washed and lymphocyte-free ${ }^{9}$ rat erythrocytes. To $1 \mathrm{ml}$ of antiserum, $0.3 \mathrm{ml}$ of packed rat erythrocytes were added. The mixture was incubated for $30 \mathrm{~min}$ at $37^{\circ} \mathrm{C}, 1 \mathrm{hr}$ at $20^{\circ} \mathrm{C}$ and $3-4 \mathrm{hr}$ at $4^{\circ} \mathrm{C}$. 
The presence of heteroagglutinins was determined by a micro-haemagglutination reaction. ${ }^{10}$

In the second absorption, $1 \mathrm{ml}$ of washed and packed cell membranes from the rat liver ${ }^{11}$ was mixed with $1 \mathrm{ml}$ of rabbit antiserum and left for $1 \mathrm{hr}$ at room temperature and overnight at $4{ }^{\circ} \mathrm{C}$. The antiserum was then separated by centrifugation at $59,000 \times \mathrm{g}$ for $30 \mathrm{~min}$.

In the third absorption, anti-rat IgM and IgG antibodies were removed from rabbit anti-brain sera with rat $\operatorname{IgM}$ and $\operatorname{IgG},{ }^{12}$ which were made insoluble by means of glutaraldehyde. ${ }^{13}$ This absorption yielded rabbit antisera which did not react in $0.8 \%$ agarose $^{14}$ with rat $\mathrm{IgM}$ and $\mathrm{IgG}$.

Thymocytes ( $T$ cells) and bone marrow cells ( $B$ cells):

Thymocytes were obtained from the thymus ${ }^{15}$ of normal 6-week-old rats, and femoral marrow cells from $B$ rats of the same age. The cells were collected in medium 199, and used for absorption of rabbit antisera. B cells for the cytotoxic and immunofluorescent tests were separated on Isopaque-Ficoll. ${ }^{16}$ The viability of lymphocytes was determined by $0.2 \%$ trypan blue.

Absorption of rabbit antisera with $T$ and $B$ cells:

Rabbit anti-rat brain organelle sera, absorbed with rat erythrocytes, liver cell membranes and immunoglobulins, were further absorbed with $\mathrm{T}$ or $\mathrm{B}$ cells. For this purpose, to $1 \mathrm{ml}$ of rabbit antiserum was added $6 \times 10^{8}$ viable $\mathrm{T}$ cells or $8.5 \times 10^{8}$ viable B cells. After an incubation of $1 \mathrm{hr}$ at room temperature and $1 \mathrm{hr}$ at $4^{\circ} \mathrm{C}$, the antiserum was separated by centrifugation and stored at $-25^{\circ} \mathrm{C}$ until use.

\section{Cytoxicity test:}

The method of Konda et al. ${ }^{17}$ for serological analysis of the membrane antigen components of lymphocytes was employed. The reaction was carried out in plastic "V" plates, and the guinea-pig serum, absorbed with rat erythrocytes, liver cell membranes, serum proteins, and $\mathrm{T}$ and $\mathrm{B}$ cells, was used as a source of complement. The cytotoxic reaction was carried out as described in a previous paper, ${ }^{15}$ and the cytotoxic index was calculated as follows:

Cytotoxic index $(\%)=\frac{\% \text { dead cells in test }-\% \text { dead cells in controls (mean) }}{\% \text { viable cells in controls (mean) }} \times 100$

All cytotoxic assays were performed in duplicate and counting of cells in a haemocytometer was done independently by two observers.

Immunofluorescence:

The paraffin sections ${ }^{18}$ of the rat spinal cord, rabbit anti-rat brain sera and fluorescein isothiocyanate conjugated sheep anti-rabbit IgG serum were used in an indirect fluorescent antibody assay. ${ }^{19}$ 
The indirect fluorescent staining procedure for lymphocytes has been described in detail elsewhere. ${ }^{15}$ Several controls were set up, including the blocking test. Sections of nervous tissue and suspensions of $T$ and $B$ cells were examined under a Leitz Orthoplan fluorescence microscope equipped with BG 38, K 480, KP 490 and K 515 filters.

\section{RESULTS}

Fig. 1 shows the cytotoxic activity of rabbit anti-synaptic membrane serum before and after absorption with $\mathrm{T}$ and $\mathrm{B}$ cells. The unabsorbed antiserum was cytotoxic for both $T$ and $B$ cells, the anti- $T$ component being much more expressed. The absorption performed with $\mathrm{B}$ cells decreased the anti-T activity to a level of $80 \%$ as compared to $96 \%$ of unabsorbed serum, and completely eliminated cytotoxicity against $B$ cells. On the other hand, a single absorption with $\mathrm{T}$ cells rendered this antiserum inactive against $\mathrm{T}$ cells and reduced its reactivity with B cells to $4 \%$ as compared to $38 \%$ of unabsorbed serum.

Similar results were obtained when rabbit anti-synaptic vesicles (Fig. 2) and anti-brain microsome (Fig. 3) sera were tested for the presence of cytotoxic antibodies against $\mathrm{T}$ and $\mathrm{B}$ lymphocytes. An interesting finding was that antisynaptic vesicle serum exerted a clear cytotoxicity against $B$ cells although being absorbed with $\mathrm{T}$ cells. Even the second absorption of this antiserum with $\mathrm{T}$ cells did not abolish its anti-B activity. The inability of $T$ cells to remove the anti-B cytotoxicity from rabbit anti-synaptic vesicle serum would imply that an anti-

\section{RABBIT ANTI-RAT SYNAPTIC MEMBRANE SERUM}

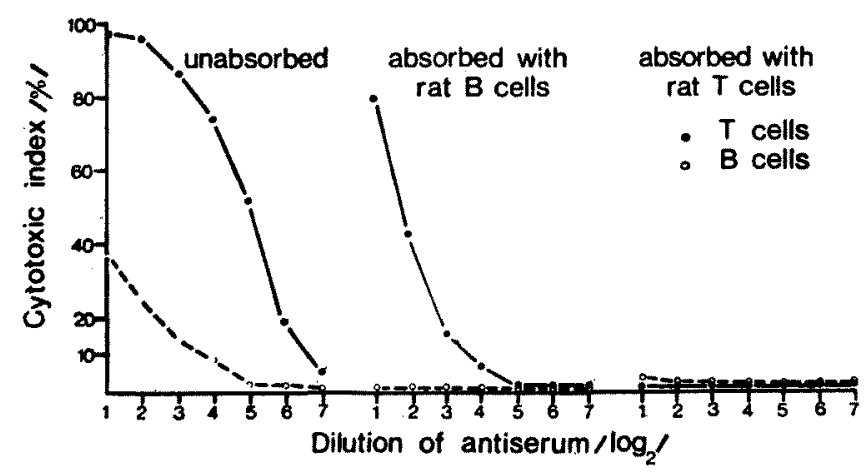

Fig. 1 Cytotoxic effects of rabbit anti-rat brain synaptic membrane serum before and after absorption with $\mathbf{B}$ and $\mathbf{T}$ cells. 


\section{RABBIT ANTI-RAT SYNAPTIC VESICLE SERUM}

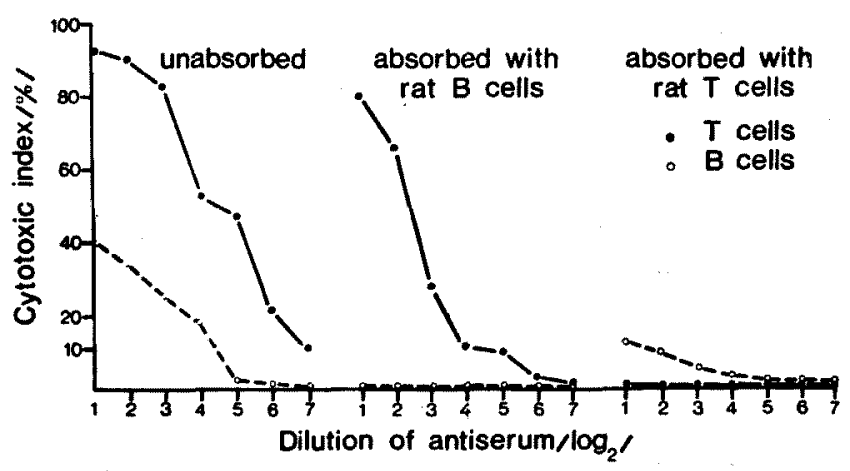

Fig. 2 Cytotoxic effects of rabbit anti-rat brain synaptic vesicle serum before and after absorption with $\mathrm{B}$ and $\mathrm{T}$ cells. Antiserum absorbed with rat erythrocytes, liver cell membranes, immunoglobulins and $\mathrm{T}$ cells exhibits a cytotoxicity (14\%) against $B$ cells only.

\section{RABBIT ANTI-RAT BRAIN MICROSOME SERUM}

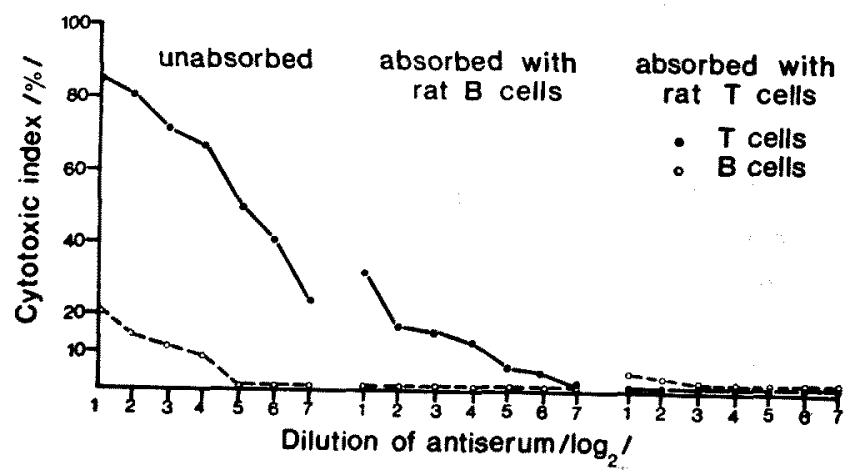

Fig. 3 Cytotoxic effects of rabbit anti-rat brain microscome serum before and after absorption with $B$ and $T$ cells.

genic determinant specific for B cells is shared by brain and B cells.

In absorption experiments performed with $B$ cells, a striking decrease of cytotoxicity against $\mathrm{T}$ cells was observed in anti-brain microsome serum since its anti- $\mathrm{T}$ activity dropped from $86 \%$ (unabsorbed serum) to $33 \%$. These 
changes in cytotoxic activity due to the absorption of anti-rat brain sera with $T$ and $B$ cells may indicate that the rat lymphocytes possess at least three serologically distinctive antigenic determinants: Thy-1 antigen, which is specific for $T$ cells; $B$ antigen, which is specific for B cells ; and $C$ antigen, which is present in both $\mathrm{T}$ and $\mathrm{B}$ cells ( $\mathrm{C}$ stands for "common").

As for the quantitative distribution of Thy-1, B and $\mathrm{C}$ antigens among subcellular fractions of the rat brain, the results of cytotoxic tests after absorption with the same number of viable $\mathrm{T}$ or $\mathrm{B}$ cells suggest that concentrations of Thy-1, $\mathrm{B}$ and $\mathrm{C}$ antigens are different in the organelles of the rat brain (Table 1 ).

Table 1

Relative distribution* of lymphocyte antigens in subcellular fractions of the rat brain

\begin{tabular}{lccc}
\hline \hline Antigen & $\begin{array}{c}\text { Synaptic } \\
\text { membranes }\end{array}$ & $\begin{array}{c}\text { Synaptic } \\
\text { vesicles }\end{array}$ & $\begin{array}{c}\text { Brain } \\
\text { microsomes }\end{array}$ \\
\hline Thy -1 & +++ & +++ & + \\
B & $0( \pm)$ & + & $0( \pm)$ \\
C & + & + & +++ \\
\hline
\end{tabular}

* Calculated from values obtained in cytotoxicity assays.

The evaluation of antigen content is based on an arbitrary scale $(0, \pm,++$ and +++$)$

Synaptic membranes and vesicles probably contain more Thy-1 antigen, and brain microsomes more $\mathrm{C}$ antigen. It appears that the largest amount of $\mathrm{B}$ antigen is located in the synaptic vesicles.

Immunofluorescent assays of rabbit anti-rat brain sera revealed that antibodies from those antisera are bound specifically to the central nervous tissue. A representative section of the rat spinal cord treated first with rabbit anti-rat synaptic membrane serum and then with fluorescein conjugated sheep anti-rabbit Ig serum is shown in Fig. 4. Rabbit anti-rat brain sera, absorbed with rat erythrocytes, liver cell membranes, serum proteins and B cells, exhibited a specific staining for $\mathrm{T}$ cells (Fig. 5). On the other hand, anti-synaptic vesicle serum, which showed the most pronounced cytotoxicity for B cells following absorption with $T$ cells, gave a specific staining with $B$ cells only (Fig. 6), thus demonstrating the presence of an antigenic marker which is associated with $B$ cells. Judged by the intensity of immunofluorescence, the anti-B activity of anti-synaptic vesicle serum was less potent than the anti- $T$ activity of anti-synaptic membrane and anti-brain microsome sera. 

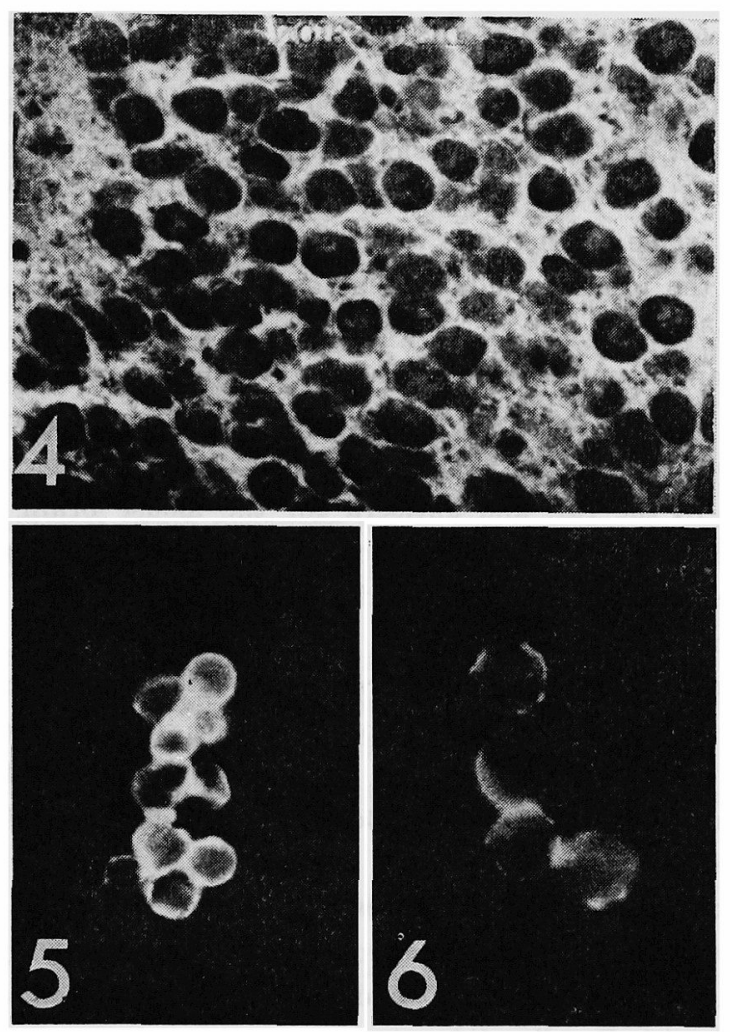

Fig. 4 Microphotograph $(\times 300)$ of a section of rat spinal cord exposed first to rabbit anti-rat synaptic membrane serum and then to fluorescein conjugated sheep anti-rabbit IgG. Neuronal membranes and interneuronal areas are brightly stained, whereas intraneuronal particulates remained unstained.

Fig. 5 Group of rat thymocytes $(\times 600)$ showing staining of high intensity. Cells are treated first with rabbit antisynaptic membrane serum (absorbed with $\mathbf{B}$ cells) and then with fluorescein conjugate. Note the ring-type and diffuse fluorescence.

Fig. 6 Four fluorescing B cells $(\times 600)$ from a rat thymectomized at birth and sublethally irradiated at 2 weeks. B cells are first exposed to rabbit antisynaptic vesicle serum (absorbed with $T$ cells) and then to fluorescein conjugated sheep anti-rabbit IgG. The cells exhibit discontinuous staining, and the intensity of fluorescence is less pronounced compared with that of $\mathbf{T}$ cells (Fig. 5). 


\section{DISCUSSION}

These results show that there is a strong cross-reactivity between antisynaptic membrane, anti-synaptic vesicle and anti-brain microsome sera, and rat $\mathbf{T}$ cells, an observation which agrees with other experiments ${ }^{2,5,20}$ in which antisera against the whole brain tissue were employed. However, an important finding revealed by the present study is that anti-synaptic vesicle serum, although properly absorbed with $T$ cells, is still capable of reacting specifically with $B$ cells in cytotoxicity and immunofluorescence assays, thus showing that rat B lymphocytes possess a specific antigenic marker. This antigenic marker is also present in the rat brain. Shigeno et al. ${ }^{21}$ failed, however, to detect specific B lymphocyte antigen in the rat, and antisera for the mouse brain were not active against mouse $B$ cells. ${ }^{22,29}$ The differences in materials used for the production of anti-brain sera may account for this discrepancy between our results and those of other investigators.

The cytotoxic effects described here were not caused by natural cytotoxic antibodies since normal rabbit sera, absorbed with rat erythrocytes, liver cell membranes and immunoglobulins, did not exhibit a quantitatively important cytotoxicity against $T$ and $B$ cells. Besides, anti-species-specific activity was removed from anti-rat brain organelle sera with rat liver cell membranes.11,24 Positive cytotoxicity and immunofluorescence obtained with $\mathrm{B}$ cells and T-absorbed anti-synaptic vesicle serum cannot be attributed to the contamination of antisera with antibodies against $\mathrm{T}$ and $\mathrm{C}$ antigens since anti-synaptic vesicle serum, absorbed with $T$ cells, did not react at all with $T$ cells, and $B$ cells remained unstained in immunofluorescent reactions with B-absorbed anti-brain sera. However, B-absorbed anti-synaptic membrane, anti-synaptic vesicle and anti-brain microsome sera produced positive reactions only with $\mathrm{T}$ cells in both cytotoxicity and immunofluorescence assays. Further, B cells were prepared from thymectomized and sublethally irradiated rats, which were proved both grossly at autopsy and histologically not to contain thymic remnants in the mediastinum and extra thymuses in the thyroid region of the neck. ${ }^{25}$ The perfusion of $B$ animals with saline before the preparation of $B$ cell suspensions minimized the risk of contamination with circulating $\mathrm{T}$ lymphocytes.

The search for the cell surface alloantigen Thy-1 in the whole brain, cerebellum and spinal cord revealed that Thy-1 is not differentially distributed among various parts of the mouse brain.26 Our results, however, indicate that the presence of Thy-1 in subcellular fractions of the rat brain differs: the synaptic membranes and vesicles contain a larger amount of Thy-1. By contrast, brain microsomes have more $\mathrm{C}$ antigen than the other two brain fractions. The quantity of $B$ antigen appears to be very small in synaptic membranes and brain microsomes, 
and somewhat more pronounced in synaptic vesicles. More et al. ${ }^{27}$ showed by immunofluorescence and cytotoxic inhibition that Thy-1 antigen of the mouse brain was predominantly located in myelinated tracts. The possibility of a cytoplasmic localization of the antigen common to brain and thymus cells should also be taken into account. ${ }^{28}$

Although anti-brain sera used in this study were prepared with defined subcellular fractions of the rat brain, they should not be considered as monospecific for a given brain antigen, since synaptic organelles have a variety of proteins and glycoproteins. ${ }^{29}$ Sequential absorption analysis of rabbit anti-rat synaptosome sera has revealed several distinctive and cross-reacting antigenic determinants in the preparation of synaptic membranes. ${ }^{30}$ The described cross-reactivity between anti-rat brain organelle antibodies and rat $T$ and $B$ cells should, therefore, be regarded as evidence for sharing of major classes of antigenic determinants by the neuron-glia units of the brain and the lymphocytes.

The cross-reactivity of rabbit anti-rat brain organelle sera with lymphocytes of different species, the serologically defined distribution of Thy-1, B and C antigenic markers in the rat spleen and lymph nodes, and the effects of these heteroantisera on cell-mediated immunity will be presented elsewhere.

\section{ACKNOWLEDGMENT}

This work was supported by grants from the Republic Research Fund of Serbia, Belgrade.

\section{REFERENCES}

1. Reif, A. E. and Allen, J. M. V.: The AKR thymic antigen and its distribution in leukemias and nervous tissues. J. Exp. Med. 120: 413, 1964

2. Douglas, T. C.: A rat analog of the mouse theta antigen. Transplant. Proc. 5: 79,1973

3. Lubaroff, D. M.: An alloantigenic marker on rat thymus and thymus-derived cells. Transplant. Proc. 5: 115, 1973

4. Raff, M. C.: Surface antigenic markers for distinguishing $T$ and $B$ lymphocytes in mice. Transplant. Rev, 6:52, 1971.

5. Peter, H.-H., Clagett, J., Feldman, J. D. and Weigle, W. O.: Rabbit antiserum to brain-associated thymus antigens of mouse and rat. I. Demonstration of antibodies cross-reacting to $T$ cells of both species. J. Immunol. 110: 1077, 1973.

6. Jankovič, B. D.: Biological activity of antibrain antibody-an introduction to immunoneurology. pp. 99-130 in Gaito, J. (ed.) Macromolecules and Behavior. Appleton-Century-Crofts. New York, 1972

7. Tashiro, Y. and Siekewitz, P.: Utracentrifugal studies on the dissociation of hepatic ribosomes. J. Nol. Biol. 11: 149, 1965

8. Lapetina, E. G., Soto, E. F. and De Robertis, E.: Gangliosides and acetylcholinesterase in isolated membranes of the rat-brain cortex. Biochim. Biophys. Acta 
135: 33,1967

9. Bobrove, A. M., Strober, S., Herzenberg, L. A. and De Pamphilis, J. D.: Identification and quantitation of thymus-derived lymphocytes in human peripheral blood. J. Immunol. 112: 520, 1974

10. Janković, B. D. and Isakovic, K.: Haemagglutinins in chickens. I. The rate of formation of naturally occurring haemagglutinins. Acta Med. Iugoslavica 14: $246,1960$.

11. Hudson, L. and Roitt, I. M.: Immunofluorescent detection of surface antigens specific to $T$ and $B$ lymphocytes in the chicken. Eur. J. Immunol. 3: 63, 1973

12. Deutsch, H. F.: Preparation of immunoglobulin concentrates. pp. $315-321$ in Williams, C. A. and Chase, M. W. (eds.) Methods in Immunology and Immunochemistry vol. 1. Academic Press. New York, 1967

13. Avrameas, S. and Ternynck, T.: The cross-linking of proteins with glutaraldehyde and its use for the preparation of immunoabsorbents. Immunochemistry 6: 53, 1969

14. Ouchterlony, O. and Nilsson, L. A.: Immunodiffusion and immunoelectrophoresis. pp. 19.1-19.39 in Weir, D. M. (ed.) Handbook of Experimental Immunology vol. 1. Immunochemistry. Blackwell. Oxford, 1973.

15. Isakovič, K., Mitrović, K., Markovič, B. M., Rajčevič, M. and Jankovič, B. D.: Preparation of specific anti-thymocyte and anti-bursacyte sera in rabbits. J. Immunol. Hethods 1975 (in press)

16. Kissmeyer-Nielsen, F. and Thorsby, E.: Current methods in histocompatibility testing. Transplant. Rev. 4: 115, 1970

17. Konda, S., Stockert, E. and Smith, R. T.: Immunologic patterns associated with various cell subpopulations. Cell. Immunol. 7: 275, 1973

18. Sainte-Marie, G.: A paraffin embedding technique for studies employing immunofluorescence. J. Histochem. Cytochem. 10: 250, 1962

19. Holborow, E. J. and Johnson, G. D.: Immunofluorescence, pp. 18.8-18.20 in Weir, D. M. (ed.) Handbook of Experimental Immunology vol. 1. Immunochemistry. Blackwell. Oxford, 1973

20. Thiele, H.-G., Stark, R. and Keeser, D.: Antigenic correlations between brain and thymus. I. Common antigenic structures in rat and mouse brain and thymocytes. Eur. J. Immunol. 2: 424, 1972

21. Shigeno, N., Arpels, C., Hämmerling, U., Boyse, E. A. and Old, L. J.: Preparation of lymphocyte-specific antibody from anti-lymphocyte serum. Lancet 2: 230, 1968

22. Golub, E. S.: The distribution of brain-associated-antigen cross-reactive with mouse in the brain of other species. J. Immunol. 109: 168, 1972

23. Thiele, H.-G. and Stark, R.: Common antibody-induced redistribution on thymocytes of strain-, species- and non-species-specific antigenic determinants shared by brain and thymocytes of mice. Immunology 27: 807, 1974

24. Day, E. D. and Appel, S. H.: The biological half-life of brain-localized antisynapse radioantibodies. J. Immunol. 104: 710, 1970.

25. Jankovič, B. D., Janežič, A. and Popeskovic, Lj.: Brown adipose tissue and immunity. Effect of neonatal adipectomy on humoral and cellular immune reactions in the rat. Immunology 1975 (in press)

26. Schachner, M.: Representation of the cell surface alloantigen Thy-1 $(\theta)$ in brains of neurological mutants of the mouse. Brain Res. 56: 382, 1973

27. Moore, M. J., Dikkes, P., Reif, A. E., Romanul, F. C. A. and Sidman, R. L.: Localization of theta alloantigens in mouse brain by immunofluorescence and cytotoxic inhibition. Brain Res. 28: 283, 1971.

28. Toh, B. H. and Cauchi, M. N.: Brain-associated tumour antigens demonstrated by immunofluorescence. Nature 250: 597, 1974

29. Morgan, I. G., Zanetta, J.-P., Breckenbridge, W. C., Vincendon, G. and Gombos, 
G.: The chemical structure of synaptic membranes. Brain Res. 62: 405, 1973

30. Mickey, D. D., McMillan, P. H., Appel, S. H, and Day, E. D.: The specificity and cross-reactivity of antisynaptosome antibodies as detected by sequential absorption analysis. J. Immunol. 107: 1599, 1971

\section{LEGENDS FOR FIGURES}

Fig. 1 Cytotoxic effects of rabbit anti-rat brain synaptic membrane serum before and after absorption with $B$ and $T$ cells.

Fig. 2 Cytotoxic effects of rabbit anti-rat brain synaptic vesicle serum before and after absorption with $B$ and $T$ cells. Antiserum absorbed with rat erythrocytes, liver cell membranes, immunoglobulins and $\mathrm{T}$ cells exhibits a cytotoxicity (14\%) against $B$ cells only.

Fig. 3 Cytotoxic effects of rabbit anti-rat brain microsome serum before and after absorption with $\mathrm{B}$ and $\mathrm{T}$ cells.

Fig. 4 Microphotograph $(\times 300)$ of a section of rat spinal cord exposed first to rabbit anti-rat synaptic membrane serum and then to fluorescein conjugated sheep anti-rabbit IgG. Neuronal membranes and interneuronal areas are brightly stained, whereas intraneuronal particulates remained unstained.

Fig. 5 Group of rat thymocytes $(\times 600)$ showing staining of high intensity. Cells are treated first with rabbit anti-synaptic membrane serum (absorbed with $B$ cells) and then with fluorescein conjugate. Note the ring-type and diffuse fluorescence.

Fig. 6 Four fluorescing $B$ cells $(\times 600)$ from a rat thymectomized at birth and sublethally irradiated at 2 weeks. B cells are first exposed to rabbit anti-synaptic vesicle serum (absorbed with $\mathrm{T}$ cells) and then to fluorescein conjugated sheep anti-rabbit IgG. The cells exhibit discontinuous staining, and the intensity of fluorescence is less pronounced compared with that of $T$ cells (Fig. 5), 